\title{
Analisa Pengaruh Influencer Social Media Terhadap Keputusan Pembelian Konsumen Generasi Z di Kota Surabaya
}

\author{
Adhimurti Citra Amalia ${ }^{1}$, Gabriella Sagita Putri ${ }^{2}$ \\ ${ }^{I}$ Public Relations Program, Bina Nusantara Institute of Creative Technology Malang, Malang, 65154 \\ E-mail: adhimurtic@gmail.com \\ ${ }^{2}$ Public Relations Program, Bina Nusantara Institute of Creative Technology Malang, Malang, 65154 \\ E-mail: gabriellasagita@gmail.com
}

\begin{abstract}
Social media influencers have now been used by many commercial brands as one of the promotional strategies to market their products. Especially for $\mathbf{Z}$ generation who are close to the use of the internet, social media, and digital media in their daily lives. Although the existence of social media influencers is on the rise, the trust of commercial brands to advertise their products on conventional media such as televisions is still quite high compare to the digital media. This issue encourages researchers to dig deeper whether social media influencers really influence the purchasing decisions of $Z$ generation consumers in Surabaya city or not. In addition to measure the influence, researchers also want to know what factors are related to social media influencers that influence the purchasing decisions of $\mathrm{Z}$ generation consumers. This research uses quantitative methods where data collection is obtained through questionnaires. The results of the research were analyzed using Pearson Product Moments and it was found that Chi-square value (239.088) > Chi-Square table (42.557) and P-value (0.000) < alpha $(0.05)$ which leads to the decline of H0, which indicates that there is an influence between social media influencers variables (independent $/ \mathrm{X}$ ) with generation $\mathrm{Z}$ consumer purchasing decision variables (dependent / Y).
\end{abstract}

Keywords —: influencer social media; marketing communication; consumer behaviour.

\section{PENDAhUlUAN}

Menyongsong revolusi industri 4.0, masyarakat Indonesia menghadapi perubahan besar yang mempengaruhi gaya belanja mereka sehari-hari. Masyarakat kini tidak perlu lagi bersusah-payah datang ke market place seperti toko, pasar, mini market, atau mall untuk membeli sesuatu karena semuanya dapat dilakukan secara online. Sebutlah Tokopedia, Shopee, Bukalapak, OLX, Lazada, atau Blibli.com, keberadaan e-commerce yang menjamur di Indonesia semakin mendukung gaya belanja konsumen melalui online. Kemudahan ini tak ayal melahirkan begitu banyak produk yang dipasarkan melalui online, sebab dapat menjangkau konsumen dengan lebih luas lagi. Tidak hanya produk baru saja, tetapi produk yang sudah lebih lama berada di pasaran atau bahkan yang sudah menyandang predikat top of mind pun ikut berpartisipasi dalam euforia dunia digital ini.

Penggunaan internet dan social media telah banyak digunakan oleh para pelaku industri sebagai salah satu strategi untuk memasarkan produk. Bentuk strategi komunikasi pemasaran produk melalui social media ini beraneka ragam. Misalnya seperti iklan, endorsement, paid promote, dan lain sebagainya. Salah satu bentuk strategi yang tengah menjadi tren oleh para pelaku industri saat ini adalah penggunaan influencer di social media. Sekilas mengenai influencer, menurut Hariyanti \& Wirapraja influencer merupakan figur pada social media, yang memiliki jumlah pengikut banyak atau signifikan yang dapat mempengaruhi atau merespon perilaku dari pengikutnya (Hariyanti \& Wirapraja, 2018: 141). Influencer berasal dari berbagai macam profesi, bisa berupa selebriti, seniman, blogger, tokoh, dan lain sebagainya.

Strategi komunikasi pemasaran produk melalui social media, khususnya influencer menjadi pilihan yang populer sebab dianggap relatif lebih murah dan efektif. Apabila dibandingkan dengan pemasangan iklan di media konvensional seperti TV, koran, atau billboard, biaya yang harus dikeluarkan memang jauh lebih mahal dibandingkan dengan social media. Zaenudin mengatakan bahwa biaya beriklan melalui influencer social media hanya membutuhkan $10 \%$ dibandingkan dengan biaya produksi dan penayangan iklan di TV. Pernyataan ini didukung oleh penelitian dari GetCRAFT yang memaparkan bahwa pada platform instagram sebanyak 37.290 views misalnya, pengiklan hanya membutuhkan biaya sekitar Rp. 590 per view (Zaenudin, A., April 22 2019). Tetapi meskipun demikian, jumlah pengiklan di social media ini masih belum bisa menyaingi media konvensional seperti televisi. Lembaga survey Nielsen menyebutkan bahwa porsi belanja iklan tahun 2017 di Indonesia masih didominasi oleh media TV sebesar $80 \%$, dari total belanja iklan yang tumbuh $12 \%$ dibanding tahun sebelumnya (Lubis, M., April 23 2019). Data ini menunjukkan bahwa kepercayaan pengiklan pada media konvensional seperti TV masih cukup tinggi dibandingkan dengan media digital seperti social media.

Kepercayaan pengiklan yang masih tinggi terhadap media konvensional seperti televisi, membuat peneliti ingin mencari tahu apa kekurangan yang terdapat pada social media khususnya influencer. Terdapat kecurigaan dari peneliti bahwa penggunaan influencer di social media hanya menyentuh level teratas pada brand equity (ekuitas merek), yaitu brand awareness atau kesadaran merek, tapi tidak sampai pada keputusan pembelian konsumen. Ada begitu banyak faktor yang mempengaruhi perilaku konsumen hingga sampai pada keputusan pembelian produk. Misalnya seperti lingkungan, pengalaman, media, sikap, 
atau status sosial seseorang (Diehl \& Karmasin, 2013: 165). Peneliti ingin menggali lebih dalam apakah influencer social media dapat menjadi salah satu faktor kuat yang berpengaruh terhadap perilaku konsumen tersebut. Oleh karena itu, untuk mengetahui sejauh mana pengaruh influencer social media terhadap keputusan pembelian konsumen diperlukan penelitian lebih lanjut.

Di antara sekian banyak konsumen yang ada dalam lapisan masyarakat, generasi Z muncul sebagai generasi yang paling menarik perhatian peneliti. Menurut Bencsik, Csikos, dan Juhez (2016), generasi Z adalah kelompok yang lahir antara rentang tahun 1995 sampai 2010 (dalam Putra, S. Y. 2016: 130). Sedangkan menurut Singh (2014), generasi Z lahir pada periode tahun 1995 sampai 2012 (Singh, 2014: 59). Apabila merujuk pada penelitian ini yang ditulis pada tahun 2019, yang dimaksud dengan generasi Z adalah kelompok yang berusia antara 7-24 tahun. Berbeda dengan generasi pendahulu mereka, seperti generasi baby boomers, generasi $\mathrm{X}$, dan generasi $\mathrm{Y}$, generasi $\mathrm{Z}$ telah bersentuhan dengan internet dan social media bahkan sejak mereka lahir. Di Indonesia, internet hadir sekitar tahun 1990 dan penyedia jasa internet komersial pertama kali diperkenalkan pada tahun 1994 melalui Indonet (Adam, A., April 14 2019). Generasi Z mengalami perkembangan social media yang datang silih berganti seperti facebook di tahun 2004, youtube di tahun 2005, twitter di tahun 2006, hingga instagram di tahun 2010, seiring dengan pertumbuhan mereka, sehingga tidak mengherankan jika social media telah menjadi bagian dari hidup generasi ini setiap harinya.

Sebagai generasi terbaru yang lahir setelah generasi Y atau generasi millenials, generasi Z dipilih karena dipandang sebagai generasi penerus bangsa di masa depan. Dari rentang usia yang dihasilkan oleh dua penelitan sebelumnya, diketahui bahwa tidak semua generasi $\mathrm{Z}$ termasuk dalam usia produktif. Beberapa di antaranya ada yang sudah memasuki dunia kerja, tetapi tidak sedikit pula yang masih berstatus pelajar atau bahkan anak-anak. Meskipun demikian, keberadaan generasi ini tetap tidak dapat diremehkan sebab dapat menjadi calon konsumen yang sangat potensial di masa mendatang. Generasi yang hari ini belum memiliki penghasilan sendiri, misalnya masih merupakan seorang pelajar SD, SMP, SMA, atau mahasiswa, dalam beberapa tahun ke depan berpotensi menjadi kaum pekerja atau enterpreneur yang menciptakan lapangan pekerjaan bagi orang lain.

Sebagai kota terbesar kedua setelah ibu kota DKI Jakarta, kota Surabaya dipilih sebagai daerah penelitian sebab menyimpan potensi ekonomi yang sangat besar di Indonesia. Berdasarkan data BPS (Badan Pusat Statistik), PDRB (Produk Domestik Regional Bruto) yang merupakan salah satu indikator yang digunakan untuk mengetahui pembangunan di sektor ekonomi, di kota Surabaya pada tahun 2017 mencapai Rp. 495 trilyun. Jumlah ini lebih besar dibandingkan dengan tahun sebelumnya, yaitu 2016 yang mencapai Rp. 451 trilyun, dan mengalami peningkatan sebesar 11\%. Di Jawa Timur, angka PDRB kota Surabaya adalah yang paling tinggi disusul dengan kota Kediri yang menempati posisi ke dua dengan angka Rp. 116 milyar dan posisi ke tiga kota Malang dengan angka Rp. 62 milyar (Alamsyah, M., 2018: 19-22).

Jumlah penduduk kota Surabaya tahun 2017 mencapai 2,87 juta jiwa dengan presentase 49,40\% berjenis kelamin laki-laki dan 50,60\% perempuan. Sedangkan jumlah penduduk usia produktif yaitu 15-64 tahun di kota Surabaya adalah yang paling dominan, mencapai 73,44\% dari total penduduk secara keseluruhan. Jumlah ini disusul oleh usia 0-14 tahun sebesar 21,66\% dan $>=65$ tahun sebesar 4,90\%. Dari angka ini diketahui bahwa jumlah penduduk yang termasuk dalam generasi Z, baik dari kelompok usia 0-14 tahun dan irisan dari kelompok usia produktif 15-24 tahun di kota Surabaya termasuk cukup besar dan layak untuk menjadi sasaran penelitian (Alamsyah, M., 2018: 4-5).

Menelusuri pemikiran generasi $\mathrm{Z}$ yang memiliki masa depan sebagai penerus bangsa, serta berpotensi besar untuk menjadi konsumen yang menjanjikan di tengah derasnya arus informasi yang didukung oleh teknologi internet ini menjadi topik hangat yang menarik untuk diteliti. Hasil penelitian ini diharapkan dapat berkontribusi tidak hanya dari sisi akademis saja, tetapi juga dalam bidang praktisi komunikasi pemasaran khususnya yang menggunakan platform digital seperti social media. Dengan demikian, berdasarkan latar belakang tersebut penelitian ini mengangkat judul mengenai "Analisis Pengaruh Influencer Social Media Terhadap Keputusan Pembelian Konsumen Generasi Z di Kota Surabaya".

\section{KERANGKA TEORI}

\section{A. Influencer}

Influencer, berasal dari kata influence atau pengaruh, yang berarti kekuatan untuk mempengaruhi seseorang, hal, atau situasi. Menurut Brown \& Hayes, influencer adalah pihak ketiga yang secara signifikan membentuk keputusan pembelian konsumen, tetapi mungkin ikut bertanggung jawab untuk itu (Brown \& Hayes, 2008: 49-50). Sedangkan influencer marketing adalah proses mengidentifikasi dan mengaktifkan individu-individu yang memiliki pengaruh terhadap target audiens tertentu untuk menjadi bagian dari kampanye produk dengan tujuan peningkatan jangkauan, penjualan, dan hubungan dengan konsumen (Sudha \& Sheena, 2017: 16).

Influencer menurut pendapat Turner, dapat dikategorikan sebagai microcelebrity yang berarti sebuah gaya baru dalam perilaku online dimana seseorang berusaha untuk meningkatkan popularitasnya di internet dengan menggunakan berbagai macam teknologi seperti video, blog, atau situs jejaring sosial (Senft, 2008: 25 dalam Rahmawan, dkk. 2017: 190-191). Microcelebrity juga bisa dipahami sebagai mindset atau praktik dimana audiens dianggap sebagai sebuah basis penggemar atau fanbase. Kepopuleran seseorang ini dikelola melalui manajemen penggemar, serta dikonstruksi secara hati-hati untuk menjadi bahan konsumsi orang lain (Marwick, 2013: 230 dalam dalam Rahmawan, dkk. 2017: 191). Fenomena microcelebrity di Indonesia sendiri akhir-akhir ini dapat terlihat melalui populernya istilah selebtwit di twitter atau selebgram di instagram, yang kehadirannya turut menyemarakkan dunia social media di kalangan para penggunanya (Krisnawati, 2016 dalam Rahmawan, dkk. 2017: 199). Kepopuleran influencer yang dianggap memiliki basis massa atau fanbase yang kuat ini kini telah 
Website : http://sosial.unmermadiun.ac.id/index.php/sosial

dimanfaatkan oleh pelaku industri atau para pemilik brand sebagai salah satu strategi komunikasi pemasaran untuk meningkatkan penjualan produknya.

Menurut Solis, aspek yang dilihat dari seorang influencer dapat dikategorikan sebagai Reach, Resonance, dan Relevance. Reach, berarti seberapa banyak pengikut atau follower yang melakukan engagement seperti like, share, retweet, comment, klik pada link URL, atau mengisi form/pembelian pada postingan yang dibuat oleh influencer. Resonance, berarti tindakan follower yang meneruskan atau membagikan lagi konten dari influencer. Sedangkan Relevance, adalah tingkat kesesuaian atau kesamaan antara nilai-nilai yang dianut oleh influencer dengan brand image produk. Relevance juga bisa berarti apakah influencer memiliki nilai, budaya, dan demografis yang sama dengan target konsumen dari produk tersebut (Solis, 2012 dalam Evelina \& Handayani, 2018: 76).

\section{B. Brand Equity}

Brand atau merek adalah sebuah nama, istilah, desain, atau kombinasinya, yang dimaksudkan untuk mengidentifikasi barang atau jasa dari salah satu penjual atau kelompok penjual dan mendiferensiasikan mereka dari para pesaingnya (Kotler, 1994: 444-445 dalam Tuominen, 1999: 66). Sedangkan brand equity atau ekuitas merek adalah sejumlah aset dan liabilitas (kewajiban) yang berhubungan dengan merek, nama, dan simbol, yang menambah atau mengurangi nilai dari produk atau pelayanan bagi perusahaan atau pelanggan perusahaan (Kotler \& Keller, 2006 dalam Khasanah, I: 2013: 97).

Brand equity ini dapat digunakan untuk mengukur keefektifan sebuah brand atau merek, yang terbagi dalam lima kategori sebagai berikut: 1. Brand awareness (kesadaran merek), yaitu kesanggupan calon pembeli untuk mengenali atau mengingat kembali bahwa suatu merek merupakan bagaimana dari kategori merek tertentu. 2. Brand association (asosiasi merek), yaitu segala sesuatu yang berkaitan secara langsung maupun tidak dengan ingatan konsumen terhadap suatu merek. 3. Perceived quality (persepsi kualitas), yaitu persepsi konsumen terhadap keseluruhan kualitas atau keunggulan suatu produk atau jasa layanan berkaitan dengan maksud yang diharapkan. 4. Brand loyalty (loyalitas merek), yaitu ukuran kesetiaan konsumen terhadap suatu merek. 5. Other assets, yaitu aset-aset hak milik lain, seperti hak paten dan saluran distribusi merek. (Aaker \& Joachimsthaler, 2000 dalam Kunto \& Agusli, 2013: 2-3).

Brand equity merupakan hasil dari persepsi konsumen yang dipengaruhi oleh beberapa faktor. Termasuk kegiatan pemasaran yang dilakukan oleh perusahaan, ini juga akan mempengaruhi persepsi konsumen mengenai suatu merek. Selanjutnya, persepsi inilah yang akan mempengaruhi minat atau keputusan pembelian dari seorang konsumen (Kunto \& Agusli, 2013: 1).

\section{Perilaku Konsumen}

Perilaku konsumen adalah studi tentang proses keterlibatan individu atau kelompok dalam memilih, membeli, menggunakan, atau membuang sebuag produk, layanan, ide, atau pengalaman untuk memuaskan kebutuhan dan keinginan mereka (Solomon, 2018: 28). Kotler \& Amstrong mengembangkan Lima Tahap Model: Proses Keputusan Pembelian, menjadi problem recognition (pengenalan masalah), information search (pencarian informasi), evaluation alternatives (evaluasi alternatif), purchase decision (keputusan pembelian), dan post purchase behavior (perilaku pasca pembelian (Kotler \& Amstrong, 2018: 175-178).

Hal yang perlu diperhatikan dalam model ini adalah tidak semua konsumen mengalami semua tahapan ini secara berurutan. Ada kemungkinan seseorang melewati beberapa tahapan atau melakukannya secara terbalik. Tetapi model ini merupakan kerangka acuan yang baik, sebab dapat memberikan gambaran tentang pertimbangan konsumen secara keseluruhan dalam membeli sebuah produk, yang dapat dilihat melalui Tabel I (Kotler \& Amstrong, 2018: 175-178).

Tabel 1. Lima Tahap Model: Proses Keputusan Pembelian (Kotler \& Amstrong)

]
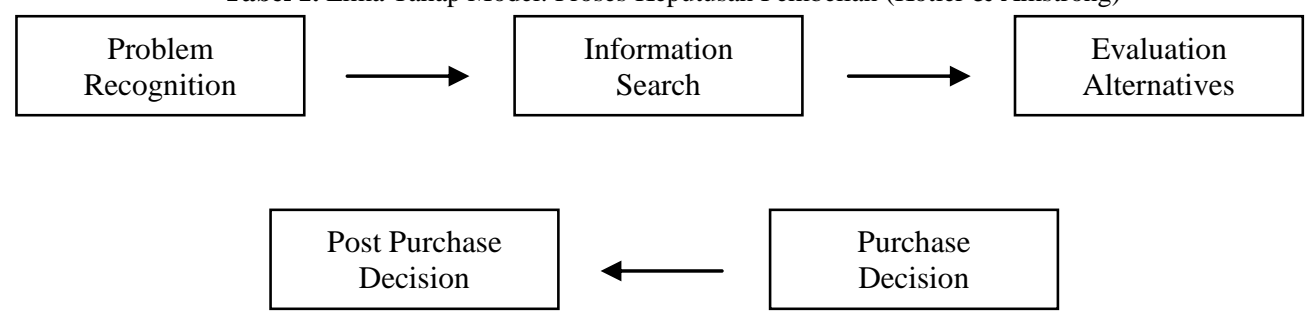

Berikut adalah penjelasan mengenai Lima Tahap Model: Proses Keputusan Pembelian: Pertama, problem recognition, dimulai ketika konsumen mengenali masalah atau kebutuhan yang dipicu oleh rangsangan internal atau eksternal. Kedua, information search, dimana sumber pencarian informasi utama bisa berasal dari personal, komersial, publik, atau pengalaman. Ketiga, evaluation of alternatives, yaitu bagaimana konsumen memproses informasi dan membuat penilaian akhir atas produk. Keempat, purchase decision, yang dapat dipengaruhi oleh dua faktor utama yaitu pertama, sikap orang lain yang meliputi sikap negatif terhadap alternatif pilihan konsumen, serta motivasi konsumen untuk patuh terhadap keinginan orang lain tersebut. Kedua, munculnya situasi yang tidak terduga yang dapat mengubah niat beli konsumen. Kelima, post purchase behavior, yang terdiri dari post purchase satisfaction (puas terhadap produk), post purchase actions (jika puas melakukan pembelian uang, jika tidak dapat meninggalkan, mengembalikan, atau berbicara yang tidak baik tentang produk kepada orang lain), dan post purchase uses and disposal (bagaimana konsumen menggunakan atau membuang produk) (Kotler \& Amstrong, 2018: 177-178). 
Website : http://sosial.unmermadiun.ac.id/index.php/sosial

\section{Generasi Z}

Generasi, menurut Manheim (1952) adalah suatu konstruksi sosial dimana di dalamnya terdapat sekelompok orang yang memiliki kesamaan umur dan pengalaman historis yang sama. Menurut penelitian Bencsik, Csikos, dan Juhez (2016) kelompok generasi terbagi seperti yang dapat terlihat dalam Tabel 2 berikut (dalam Putra, 2016: 130).

Tabel 2. Perbedaan Generasi (Bencsik, Csikos, dan Juhez)

\begin{tabular}{cc}
\hline Tahun Kelahiran & Nama Generasi \\
\hline $1925-1946$ & Veteran generation \\
$1946-1960$ & Baby boom generation \\
$1960-1980$ & X generation \\
$1980-1995$ & Y generation \\
$1995-\mathbf{2 0 1 0}$ & Z generation \\
$2010+$ & Alfa generation \\
\hline
\end{tabular}

Kelompok generasi ini memiliki karakteristiknya masing-masing, yang dihimpun dari berbagai sumber oleh peneliti sebagai berikut. Veteran generation, adalah generasi yang konservatif dan disiplin. Baby boom generation, adalah generasi yang materialistis dan berorientasi waktu (Howe \& Strauss, 1991). X generation, adalah generasi yang lahir pada awal-awal perkembangan PC (personal computer), video games, TV kabel, dan internet. Generasi ini dianggap mampu beradaptasi, menerima perubahan, tangguh, mandiri dan loyal, mengutamakan image, ketenaran, uang, dan pekerja keras (Jurkiewicz, 2000). $Y$ generation, atau yang juga dikenal sebagai generasi millenials, adalah generasi yang tumbuh di era internet booming. Sedangkan $Z$ generation, memiliki kesamaan dengan $\mathrm{Y}$ generation, tetapi generasi ini mampu mengaplikasikan semua kegiatan dalam satu waktu (multitasking) seperti menjalankan social media melalui ponsel, browsing melalui PC, dan mendengarkan musik melalui headset. (Elmore, 2014 dalam Putra, 2016: 130-132).

Perilaku konsumen pada generasi Z, dikategorikan oleh Schiffman dan Wisenblit ke dalam kelompok tweens dan teens. Tweens (pra remaja) berusia antara 8-12 tahun, sedangkan tweens (remaja) berusia 13-17 tahun. Sementara dari penelitian Bencsik, Csikos, dan Juhez (2016), diketahui bahwa individu-individu yang lahir mulai tahun 1995, juga dikategorikan ke dalam generasi Z (dalam Putra, 2016: 130.) Apabila merujuk pada penelitian ini yang dilakukan tahun 2019, berarti kelompok yang berusia sampai 24 tahun juga bisa digolongkan ke dalam generasi $\mathrm{Z}$.

\section{III.DESAIN PENELITIAN}

Berdasarkan kerangka teori yang sudah dipaparkan sebelumnya, maka peneliti membuat desain penelitian yang dapat dijelaskan melalui variabel-variabel dalam Tabel 3 berikut.

Tabel 3. Desain Penelitian

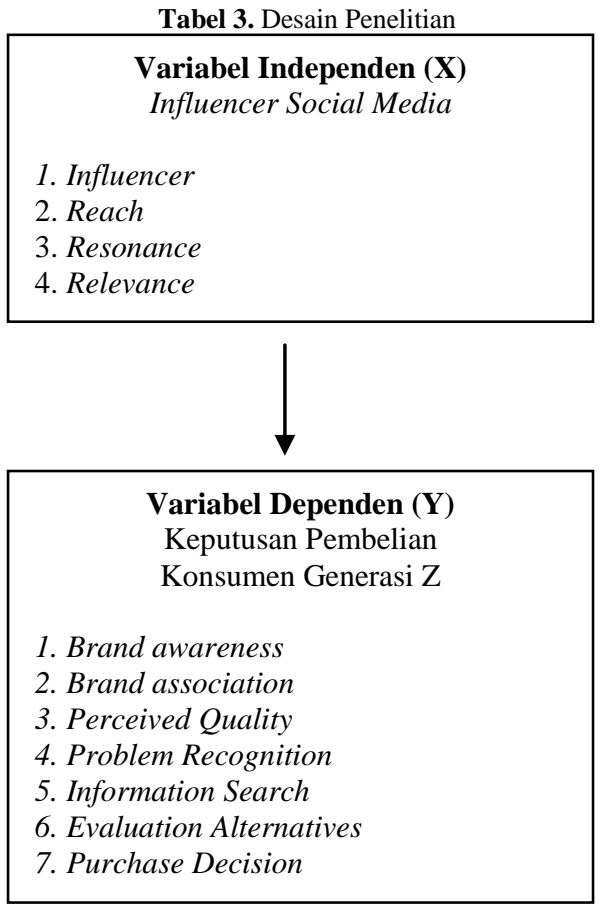


Website : http://sosial.unmermadiun.ac.id/index.php/sosial

Variabel bebas yang digunakan dalam penelitian ini adalah influencer social media, sedangkan variabel terikat adalah keputusan pembelian konsumen generasi $\mathrm{Z}$.

Hipotesis

Dalam penelitian ini, peneliti merumuskan hipotesis sebagai berikut:

Ho: Tidak ada pengaruh pada influencer social media terhadap keputusan pembelian konsumen generasi Z di kota Surabaya.

Hi: Ada pengaruh pada influencer social media terhadap keputusan pembelian konsumen generasi Z di kota Surabaya.

\section{IV.METODE PENELITIAN}

Pendekatan yang digunakan dalam penelitian ini adalah kuantitatif dengan metode survei yang bersifat deskriptif. Wallace (1973) menggambarkan penelitian survei sebagai proses untuk mentransformasikan lima komponen informasi ilmiah yang terdiri atas teori, hipotesis, observasi, generalisasi empiris, serta penolakan atau penerimaan hipotesis penelitian (dalam Suyatno \& Sutinah, 2007: 41). Dengan metode survei, peneliti memilih sejumlah responden sebagai sampel penelitian. Kemudian instrumen penelitian yang digunakan adalah kuesioner untuk mengumpulkan data penelitian. Kuesioner sendiri merupakan daftar pertanyaan terstruktur untuk memperoleh data berupa jawaban-jawaban dari para responden. Teknik pengumpulan data penelitian ini digolongkan menurut asal sumbernya, yaitu berupa data primer dan data sekunder. Data primer adalah data yang diperoleh langsung dari objek yang diteliti. Sedangkan data sekunder adalah data yang diperoleh dari lembaga atau institusi tertentu, seperti Biro Pusat Statistik, berita, jurnal, buku, atau penelitian yang sudah ada sebelumnya (Koentjaraningrat, 1977: 173 dalam Suyatno \& Sutinah, 2007: 55-56). Variabel yang digunakan dalam penelitian ini berjumlah dua variabel, yaitu influencer social media sebagai variabel independen $(\mathrm{X})$ dan keputusan pembelian konsumen generasi $\mathrm{Z}$ sebagai variabel dependen (Y).

Populasi merupakan keseluruhan objek yang diteliti, sedangkan sampel merupakan sebagian dari objek yang diteliti Suyatno \& Sutinah, 2007: 139). Populasi dalam penelitian ini adalah individu-individu yang termasuk dalam generasi Z, berusia 17-24 tahun dan berdomisili di kota Surabaya. Peneliti tidak memasukkan rentang usia tweens (8-14 tahun) dan teens (15-16), karena dianggap belum memasuki usia dewasa dan keputusan yang diambil masih banyak berdasarkan dari orangtua (Schiffman dan Wisenblit, 2018: 328-329). Oleh karena itu peneliti fokus pada usia 17-24 tahun, dimana populasi merupakan individu yang sudah memiliki KTP (Kartu Tanda Penduduk) dan berprofesi sebagai mahasiswa, pekerja muda, dan lain sebagainya.

Dari pernyataan di atas diketahui bahwa teknik pengambilan sampel yang digunakan dalam penelitian ini adalah stratified random sampling, dimana populasi ditentukan berdasarkan tingkatan tertentu, setelah itu baru dilakukan pengacakan (Suyatno \& Sutinah, 2007: 139). Berdasarkan teknik pengambilan sampel tersebut, peneliti menetapkan jumlah sampel sebesar 100 responden yang termasuk dalam generasi Z, terdiri dari individu-individu yang terbagi dalam dua kelompok usia, yaitu 17-20 tahun dan 21-24 tahun, serta berjenis kelamin laki-laki dan perempuan sebagaimana yang terlihat dalam Tabel 4 sebagai berikut.

Tabel 4. Distribusi Responden

\begin{tabular}{|c|c|c|c|c|}
\hline \multirow{2}{*}{ Sampel } & \multicolumn{3}{|c|}{ Gender } & \multicolumn{2}{c|}{ Age } \\
\cline { 2 - 6 } & Male & Female & 17-20 tahun & $\mathbf{2 1 - 2 4}$ tahun \\
\hline \multirow{2}{*}{ Jumlah } & 36 & 64 & 43 & 57 \\
\hline Total & \multicolumn{3}{|c|}{100} & \multicolumn{2}{c|}{100} \\
\hline
\end{tabular}

Teknik pengumpulan data melalui kuesioner dibuat secara sistematis, yang berisi rangkaian daftar pertanyaan berdasarkan beberapa indikator untuk mengukur masing-masing variabel. Penyebaran kuesioner dilakukan untuk mengetahui sejauh mana pengaruh influencer social media terhadap keputusan pembelian konsumen, khususnya generasi Z di kota Surabaya. Pertanyaan dalam kuesioner ini bersifat tertutup, dimana pada pertanyaan tertutup opsi jawaban sudah ditentukan lebih dulu, sehingga responden langsung bisa memilih opsi jawaban yang tersedia di kuesioner.

Dalam teknik pengolahan data penelitian, untuk memberikan skor pada setiap jawaban responden peneliti menggunakan skala likert. Menurut Sugiyono, skala likert dapat digunakan untuk mengukur sikap, pendapat, dan persepsi terkait kejadian atau gejala sosial. Sedangkan teknik analisis data setelah seluruh data diperoleh menggunakan metode analisa korelasi Pearson Product Moment. Metode analisa ini berfungsi untuk mengetahui hubungan antara dua variabel dari data yang berbentuk interval, serta membuktikan hipotesis hubungan antara dua variabel yang bersangkutan (Sugiyono, 2015: 147).

\section{HASIL PENELITIAN DAN PEMBAHASAN}

Hasil analisa data yang diperoleh dalam penelitian ini mengarah pada pembuktian hipotesis untuk melihat ada atau tidak adanya pengaruh antara influencer social media terhadap keputusan pembelian konsumen generasi Z di kota Surabaya. Pengujian hipotesis dilakukan menggunakan uji statistik Product Moment, dengan hasil sebagai berikut.

Uji korelasi antara variabel influencer social media (independen/X) dan variabel keputusan pembelian konsumen generasi $\mathrm{Z}$ $($ dependen/Y) menghasilkan nilai Chi-square $(239,088)>$ Chi-Square tabel $(42,557)$ dan P-value $(0,000)<$ alpha $(0,05)$ sehingga keputusan yang diambil adalah tolak $\mathbf{H}_{\mathbf{0}}$. Dengan demikian, terlihat bahwa ada pengaruh antara variabel influencer social media (independen/X) dengan variabel keputusan pembelian konsumen generasi Z (dependen/Y). 
Skala likert digunakan untuk mengukur persepsi responden mengenai pengaruh influencer social media terhadap keputusan pembelian konsumen generasi Z, dan ditemukan bahwa jawaban paling tinggi adalah ragu-ragu sebesar 51\%, disusul dengan setuju sebesar 21\%, sangat setuju sebesar 3\%, tidak setuju sebesar 20\% dan sangat tidak setuju sebesar 5\%. Dari hasil ini terlihat bahwa influencer social media memang berpengaruh terhadap keputusan pembelian konsumen generasi Z, tetapi diikuti dengan tingkat keragu-raguan yang cukup tinggi sementara jawaban jawaban setuju dan tidak setuju terbilang cukup berimbang satu sama lain, seperti yang tertera dalam Gambar 1 berikut.

Gambar 1. Pengaruh Variabel X (Influencer Social Media) Terhadap Variabel Y (Keputusan Pembelian Konsumen Generasi Z)

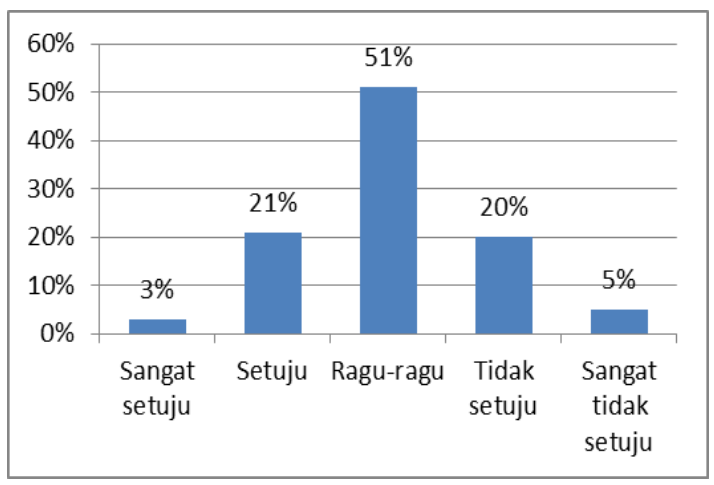

Penemuan ini menarik karena sebagai generasi yang dekat dengan penggunaan internet, social media, dan media digital dalam kehidupan sehari-hari, generasi $\mathrm{Z}$ ternyata masih cukup berhati-hati dalam mengambil keputusan untuk membeli sebuah produk. Padahal hampir seluruh responden mengaku merupakan pengguna aktif social media, yang mana paling tinggi mengakses platform social media instagram sebesar $70 \%$ dengan waktu mengakses $>$ dari 3 jam per hari, disusul dengan youtube sebesar $14 \%$ dengan waktu mengakses > dari 3 jam per hari, twitter sebesar $12 \%$ dengan waktu mengakses < dari 1 jam per hari dan facebook sebesar $4 \%$ dengan waktu mengakses < dari 1 jam per hari, seperti yang tertera dalam Gambar 2 berikut.

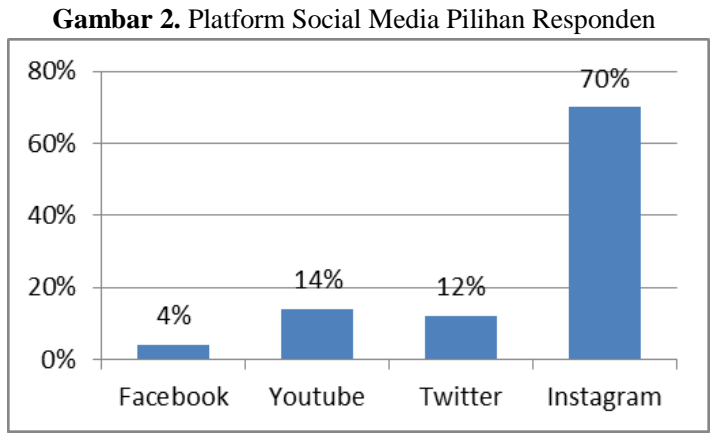

Keberadaan influencer social media memang cukup berpengaruh terhadap keputusan pembelian produk, tetapi tidak sertamerta menjadikan generasi $\mathrm{Z}$ gelap mata percaya $100 \%$ kepada influencer tanpa mempertimbangkan faktor-faktor lainnya. Dari hasil jawaban setuju dan sangat setuju, ditemukan variabel lain (independen/X) yang turut pula mempengaruhi keputusan pembelian konsumen (dependen/Y), adalah kualitas konten influencer, image influencer, reach yang ditujukkan melalui jumlah follower, like, dan comment, resonance yang ditunjukkan melalui share, dan relevance yang ditunjukkan melalui kesamaan profile influencer dengan pribadi responden, seperti yang terlihat dalam Gambar 3 berikut.

Gambar 3. Faktor-faktor Influencer Social Media yang Mempengaruhi Keputusan Pembelian Konsumen Generasi Z

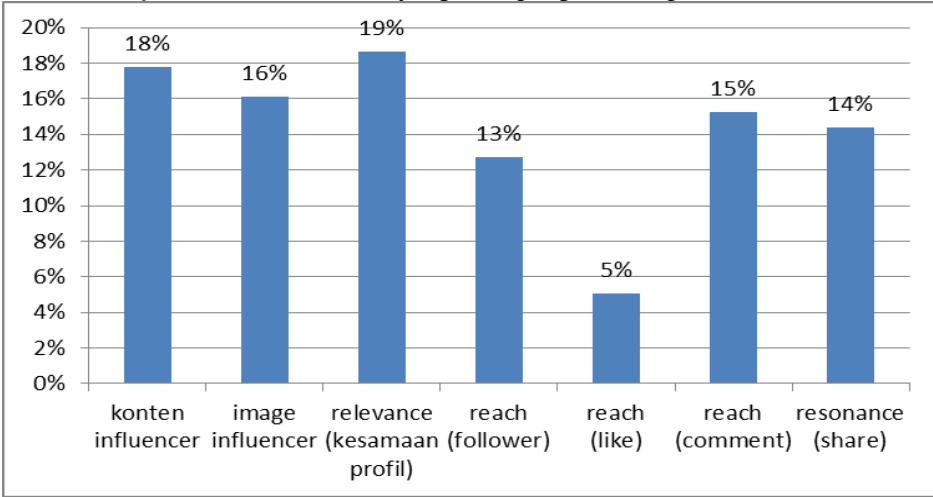


Website : http://sosial.unmermadiun.ac.id/index.php/sosial

Dari hasil penelitian ditemukan bahwa relevance memperoleh angka tertinggi sebesar 19\%, disusul dengan kualitas konten influencer sebesar 18\% dan image influencer sebesar 16\%. Reach yang diwakili oleh comment berpengaruh sebesar $15 \%$, disusul dengan resonance yang diwakili oleh share berpengaruh sebesar 14\%. Sementara reach yang diwakili oleh jumlah follower berpengaruh sebesar 13\%, dan yang paling sedikit berpengaruh adalah reach yang diwakili oleh jumlah like yang hanya memperoleh angka sebesar $5 \%$.

Sebelum sampai pada tahap keputusan pembelian konsumen, peneliti ingin mengetahui apakah influencer social media berpengaruh pula terhadap brand equity seperti brand awareness, brand association, dan perceived quality, serta perilaku konsumen mulai dari problem recognition, information search, sampai evaluation alternatives. Uji korelasi menunjukkan bahwa nilai Chi-square > Chi-Square tabel dan P-value < alpha, sehingga keputusan yang diambil semuanya adalah tolak $\mathbf{H}_{0}$ atau berpengaruh. Untuk lebih lengkapnya, berikut adalah hasil uji korelasi yang didapatkan oleh peneliti sebagai berikut:

1. Pengaruh influencer social media terhadap brand awareness.

Nilai Chi-square $(136,657)>$ Chi-Square tabel $(43,773)$ dan P-value $(0,000)<$ alpha $(0,05)$. Sehingga keputusan yang diambil adalah tolak $\mathrm{H}_{0}$.

2. Pengaruh influencer social media terhadap brand association.

Nilai Chi-square $(250,068)>$ Chi-Square tabel $(42,557)$ dan P-value $(0,000)<$ alpha $(0,05)$. Sehingga keputusan yang diambil adalah tolak $\mathrm{H}_{0}$.

3. Pengaruh influencer social media terhadap perceived quality.

Nilai Chi-square $(262,325)>$ Chi-Square tabel $(42,557)$ dan P-value $(0,000)<$ alpha $(0,05)$. Sehingga keputusan yang diambil adalah tolak $\mathrm{H}_{0}$.

4. Pengaruh influencer social media terhadap problem recognition.

Nilai Chi-square $(249,192)>$ Chi-Square tabel $(42,557)$ dan P-value $(0,000)<$ alpha $(0,05)$. Sehingga keputusan yang diambil adalah tolak $\mathrm{H}_{0}$.

5. Pengaruh influencer social media terhadap information search.

Nilai Chi-square $(273,646)>$ Chi-Square tabel $(42,557)$ dan P-value $(0,000)<$ alpha $(0,05)$. Sehingga keputusan yang diambil adalah tolak $\mathrm{H}_{0}$.

6. Pengaruh influencer social media terhadap evaluation alternatives.

Nilai Chi-square $(249,192)>$ Chi-Square tabel $(43,773)$ dan P-value $(0,000)<$ alpha $(0,05)$. Sehingga keputusan yang diambil adalah tolak $\mathrm{H}_{0}$.

Pada brand equity, hasil penelitian menunjukkan bahwa influencer social media berpengaruh paling tinggi terhadap brand awareness sebesar 43\%, disusul dengan brand association sebesar 33\%, dan yang paling rendah adalah perceived quality sebesar $23 \%$, seperti yang tertera pada Gambar 4 berikut.

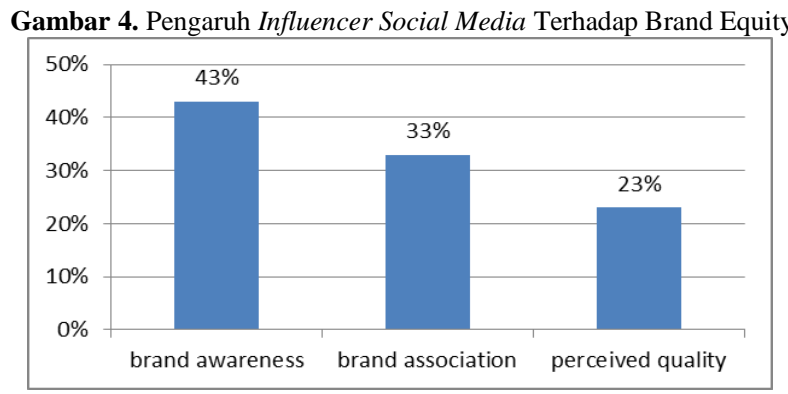

Artinya, influencer social media membuat responden mengenali dan mengingat produk, tetapi belum tentu membuat responden memiliki persepsi bahwa produk tersebut memiki kualitas yang baik. Data ini dapat menjadi salah satu faktor mengapa meskipun influencer social media berpengaruh terhadap keputusan pembelian konsumen, tetapi tingkat keraguraguannya cukup tinggi karena kepercayaan konsumen terhadap kualitas produk yang diiklankan oleh influencer cukup rendah, hanya menyentuh angka $23 \%$ apabila dibandingkan dengan brand awareness dan brand association.

Sedangkan pada perilaku konsumen yang lain, influencer social media berpengaruh terhadap problem recognition sebesar $23 \%$, information search sebesar 45\%, sampai evaluation alternatives sebesar 32\%, seperti yang tertera pada Gambar 5 berikut. 
Website : http://sosial.unmermadiun.ac.id/index.php/sosial

Gambar 5. Pengaruh Influencer Social Media Terhadap Perilaku Konsumen

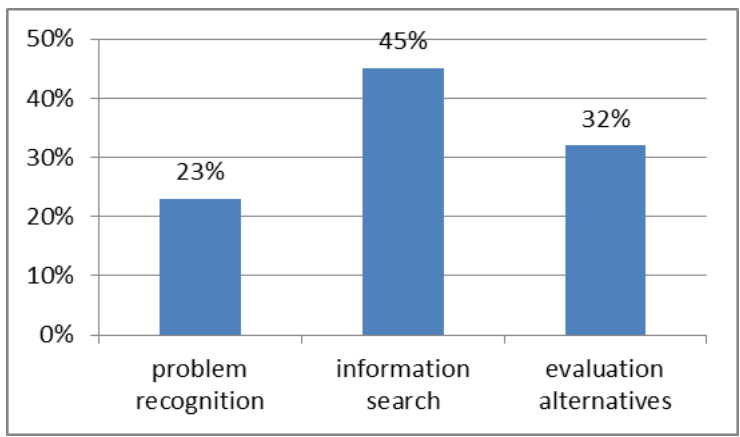

Data ini menunjukkan bahwa influencer social media berpengaruh paling tinggi terhadap information search atau proses pencarian informasi terhadap produk sebesar 45\%. Influencer social media juga cukup berpengaruh terhadap evaluation alternatives atau proses mempertimbangkan dalam membeli sebuah produk sebesar 32\%, tetapi hanya mampu membuat responden tertarik untuk membeli produk sebesar $23 \%$ (problem recognition). Data ini juga dapat menjadi salah satu faktor mengapa meskipun influencer social media berpengaruh terhadap keputusan pembelian konsumen, tetapi tingkat keraguraguannya cukup tinggi karena ketertarikan untuk membeli produk yang diiklankan influencer cukup rendah, hanya menyentuh angka 23\% apabila dibandingkan dengan information search dan evaluation alternatives.

\section{VI.KESIMPULAN}

Dari hasil analisa data yang digunakan untuk melihat ada atau tidak adanya pengaruh antara influencer social media terhadap keputusan pembelian konsumen generasi Z, diperoleh nilai Chi-square $(\mathbf{2 3 9 , 0 8 8 )}>$ Chi-Square tabel $(42,557)$ dan P-value $\left(\mathbf{0 , 0 0 0 )}\right.$ < alpha $(\mathbf{0 , 0 5})$ yang mengarah pada tolak $\mathbf{H}_{\mathbf{0}}$, yang menunjukkan bahwa ada pengaruh antara variabel influencer social media (independen/X) dengan variabel keputusan pembelian konsumen generasi Z (dependen/Y). Data didapatkan melalui skala likert yang juga menunjukkan bahwa influencer social media berpengaruh terhadap keputusan pembelian konsumen generasi Z, tetapi diikuti dengan tingkat keragu-raguan yang cukup tinggi. Generasi $\mathrm{Z}$ ternyata masih cukup berhatihati dalam mengambil keputusan untuk membeli sebuah produk. Padahal hampir seluruh responden mengaku merupakan pengguna aktif social media, yang paling tinggi mengakses platform social media instagram sebesar $70 \%$.

Keberadaan influencer social media memang cukup berpengaruh terhadap keputusan pembelian produk, tetapi generasi Z masih melihat faktor lain seperti kualitas konten influencer (18\%), image influencer (16\%), reach yang ditujukkan melalui jumlah follower (13\%), like (5\%), dan comment (15\%), resonance yang ditunjukkan melalui share (14\%), dan relevance yang ditunjukkan melalui kesamaan profile influencer dengan pribadi responden (19\%). Selain itu, hasil penelitian juga menunjukkan bahwa influencer social media berpengaruh paling tinggi terhadap brand awareness sebesar 43\%, disusul dengan brand association sebesar $33 \%$, dan yang paling rendah adalah perceived quality sebesar $23 \%$. Sedangkan pada perilaku konsumen yang lain, influencer social media berpengaruh paling tinggi terhadap information search sebesar 45\%, disusul evaluation alternatives sebesar 32\%, dan yang paling rendah adalah problem recognition sebesar $23 \%$. Data ini dapat menjadi faktor mengapa mengapa meskipun influencer social media berpengaruh terhadap keputusan pembelian konsumen, tetapi tingkat keragu-raguannya cukup tinggi karena perceived quality dan problem recognition-nya cukup rendah.

Dari hasil penelitian tersebut, saran yang diberikan peneliti khususnya terhadap pemilik brand yang menggunakan influencer social media untuk mempromosikan produknya adalah untuk tidak berpuas diri terhadap strategi yang sudah dilakukan. Influencer social media memang berpengaruh terhadap keputusan pembelian produk konsumen generasi Z, tetapi di sisi lain konsumen juga memiliki tingkat keraguan yang cukup tinggi terhadap influencer social media yang berdampak pada kehatihatian konsumen dalam membeli sebuah produk. Para pelaku industri atau pemilik brand hendaknya lebih memperhatikan faktor-faktor lain yang yang dapat mempengaruhi keputusan pembelian konsumen seperti konten influencer, image influencer, serta reach, resonance dan relevance. Para pemilik brand juga hendaknya memperhatikan bahwa influencer social media berpengaruh tinggi terhadap brand awareness, brand association, information search, dan evaluation alternatives, tetapi kurang berpengaruh pada perceived quality, dan problem recognition. Oleh karena itu meskipun influencer social media ini tengah naik daun, sebaiknya tidak digunakan sebagai satu-satunya strategi komunikasi pemasaran untuk mempromosikan sebuah produk. Promosi online yang gencar dilakukan dengan influencer social media sudah baik dilakukan oleh pemilik brand, tetapi tidak ada salahnya untuk lebih meningkatkan promosi offline supaya didapatkan hasil yang seimbang yang dapat mempengaruhi keputusan pembelian konsumen. 
Website : http://sosial.unmermadiun.ac.id/index.php/sosial

\section{DAFTAR PUSTAKA}

Adam, A. (2019, April 14). Selamat Tinggal Generasi Milenial, Selamat Datang Generasi Z. tirto.id. Retrieved from https://tirto.id/selamat-tinggal-generasimilenial-selamat-datang-generasi-z-cnzX.

Alamsyah, M. 2018. Statistik Daerah Kota Surabaya 2018. Surabaya: Badan Pusat Statistik Kota Surabaya.

Chaffey, D. \& Ellis-Chadwick, F. 2016. Digital Marketing: Strategy, Implementation and Practice. Harlow: Pearson Education.

Brown, D. \& Hayes, N. 2008. Influencer Marketing: Who Really Influences Your Customers? Oxford: Elsevier.

Diehl, S. \& Karmasin, M. 2013. Media \& Convergence Management. Berlin Heidelberg: Springer-Verlag.

Evelina, L. W. \& Handayani, F. 2018. Penggunaan Digital Influencer dalam Promosi Produk (Studi Kasus Akun Instagram @ bylizzieparra). Warta ISKI (Vol. 1, No. 1 2018: 71-82)

Gulamali, A. \& Persson, J. 2017. The Social Media Influencer \& Brand Switching. Thesis Lund University.

Hariyanti, T. N \& Wirapjaja, A. 2018. Pengaruh Influencer Marketing Sebagai Strategi Pemasaran Digital Modern (Sebuah Studi Literatur). Jurnal EKSEKUTIF (Vol. 5, No. 1 Juni 2018: 133-146).

Kotler, P. \& Amstrong, G. 2018. Principles of Marketing. Harlow: Pearson Education.

Kunto, Y. S. \& Agusli, D. 2013. Analisa Pengaruh Dimensi Ekuitas Merek Terhadap Minat Beli Konsumen Midtown Hotel Surabaya. Jurnal Manajemen Pemasaran Petra (Vol. 1, No. 2 2017: 1-8).

Lubis, M. (2019, April 23). Pertumbuhan Belanja Iklan 2017 Bergerak Positif Namun Melambat. nielsen.com. Retrieved from https://www.nielsen.com/id/en/press-room/2018/Pertumbuhan-Belanja-Iklan-2017-Bergerak-Positif-Namun-Melambat.html.

Mahoney, M. L. \& Tang, T. 2017. Strategic Social Media: From Marketing to Social Change. West Sussex: John Wiley \& Sons, Inc.

Putra, Y. S. 2016. Theoritical Review: Teori Perbedaan Generasi. (Jurnal Among Makarti Vol. 9, No. 18, Desember 2016: 123-134).

Rahmawan, dkk. 2017. Peran Vlogger sebagai Online Influencer dalam Industri Media Digital di Indonesia. PROMEDIA (Vol. 3, No. 2 2017: 183-206).

Richard, M. (2019, April 23). Belanja Iklan di Media Digital Kian Meningkat. ekonomi.bisnis.com. Retrieved from https://ekonomi.bisnis.com/read/20181215/12/869801/belanja-iklan-di-media-digital-kian-meningkat.

Singh, A. 2014. Challenges and Issues of Generation Z. IOSR Journal of Bussiness and Management (Vol. 16, Issue 7, Ver. 1 July 2014: 59-63).

Schiffman, L. G. \& Wisenblit, L. J. 2015. Consumer Behavior. Harlow: Pearson Education.

Solomon, M. R. Consumer Behavior: Buying, Having, and Being. Harlow: Pearson Education.

Sudha, M. \& Sheena, K. 2017. Impact of Influencers in Consumer Decision Process: The Fashion Industry. SCMS Journal of Indian Management (July September 2014: 14-30).

Sugiyono. 2015. Metode Penelitan dan Pengembangan. Bandung: Alfabeta.

Suyanto, B. \& Sutinah. 2007. Metode Penelitan Sosial: Berbagai Alternatif Pendekatan. Jakarta: Kencana.

Tuominen, P. 1999. Managing Brand Equity. Turku School of Economics and Business Administration LTAI (99), 65-100

Zainudin, A. (2019, April 22). Influencer di Media Sosial Penantang Tangguh Iklan Konvensional. tirto.id. Retrieved from https://tirto.id/influencer-di-mediasosial-penantang-tangguh-iklan-konvensional-cEfr. 